УДК: 378:378.14:005.591.3

DOI: 10.26697/ijes.2019.4.7

\section{Перспектива розвитку вищої освіти в Україні: ключові напрямки}

\author{
Дубова Л. В. ${ }^{1}$ \\ ${ }^{1}$ Криворізький коледж економіки та управління \\ Державного вищого навчального закладу \\ «Київський національний економічний університет \\ імені Вадима Гетьмана», Україна
}

\begin{abstract}
Резюме
Вступ:

Всім відомо, що при зміні влади освіта завжди піддається реформуванню. Тож сьогоденну державу і iii народ важко уявити без достатньої уваги до освіти та науки в цілому. Вища освіта - це фундамент на якому базується прогрес людства. А отже, при реформуванні освіти повинно забезпечуватись випуск з лав навчального закладу фахівців, які уміють самостійно мислити, творчо підходити до своєї роботи, також потрібно покращувати якість професійних знань спеціаліста, що відповідають умовам ринкової економіки. Реформування актуальне, тому що на ринку праці економічна система переходить до інформаційного типу зайнятості. Виходячи з цього, держава в галузі вищої освіти повинна забезпечити: умови, які будуть збільшувати конкурентноспроможність фахівців на ринку праці, сформувати державне замовлення на професійну освіту, збільшити якість підготовки здобувачів освіти, забезпечити взаємодію ВНЗ з роботодавцями і поліпшити мотивацію студентів та викладачів.

Мета публікації: висвітлення питань реформування вищої освіти в Україні, визначити іiі ключові напрямки.
\end{abstract}

\section{Методи:}

Для реалізації мети та завдань даної роботи були використані наступні методи дослідження: ціннісний, діалектичний, системний.

Результати:
Вивчаючи соціологічне дослідження
консалтингової компанії “Active Groupe”, основним питанням якої була якість вищої освіти в Україні, респонденти оцінили освіту на трійку. В опитуванні приймало участь 10000 осіб, які мешкають в обласних центрах України. 54\% опитаних покладають всі повноваження для виправлення даної ситуації на центральні органи влади, вони вважають, що держава занадто слабко контролює освітній процес. $45 \%$ респондентів відповіли, що держава повинна бути замовником вищої освіти. 34\% опитаних відповіли, що хотіли б здобувати освіту за кордоном. Це дало б можливість влаштуватися на роботу за кордоном, або покращити конкурентоспроможність на вітчизняному ринку праці. Проаналізувавши дане дослідження, можна зробити висновок, що ВНЗ розвиваються без урахування потреб молоді.
В Україні змінилась структура освіти. Для прикладу, освітньо-кваліфікаційний рівень бакалавр являється найвищим ступенем професійно-технічної освіти, а також перший ступінь вищої освіти. Відсутня законодавча та наукова визначеність рівнів вищої освіти. У зв'язку iз чим доводиться наймати фахівців різного рівня кваліфікації, що не завжди призводить до покращення економічних показників. У освітньокваліфікаційному рівні магістр в нашій країні відсутній конкретний статус, він ближче до спеціаліста, ніж до кандидата наук. Проте в європейських країнах магістр являється науковим рівнем.

Реорганізація вищої освіти повинна використовувати інноваційні підходи щодо питання фінансування, модернізацію системи управління навчальним закладом, змінити методи навчання студентів. Адже молодь нашої країни не спроможна працевлаштуватися та зростати в кар'єрі без здобутої вищої освіти.

\begin{abstract}
Висновки:
Щоб відбувалися зміни, потрібні сміливі управлінські дії, а також залучення ресурсів. У ВНЗ повинна бути автономія. Сьогодні навчальні заклади України не мають права розробляти та приймати до використання нові навчальні програми, на відміну від країн Європейського Союзу. Якщо вести мову про фінансову незалежність, то заклади вищої освіти України не можуть вільно розпоряджатися коштами, які вони самі заробляють і це, не кажучи вже, про державні кошти. Також не слід забувати про пільгове навчання, воно повинне бути не тільки за соціальними програмами, а й для студентів, які мають високі показники рейтингу навчання.

Дотримуючись цих простих, але необхідних вимог, можна покращити якість сучасної освіти в Україні та вийти на світовий конкурентоспроможний ринок випускників вищих навчальних закладів.
\end{abstract}

\begin{abstract}
Інформація про автора:
Дубова Лілія Василівна - викладач, Криворізький коледж економіки та управління Державного вищого навчального закладу "Київський національний економічний університет імені Вадима Гетьмана", діловод методичного кабінету, Кривий Ріг, Україна.

Наукові інтереси: формування практичнопроцесуальних вмінь 3 організації самостійної освітньої діяльності у здобувачів освіти; https://orcid.org/0000-0001-7779-8944.
\end{abstract}

\section{Автор-Кореспондент: \\ Дубова Лілія Василівна}

Email Автора-Кореспондента:

lilit03051992@gmail.com 